Deze rubriek is een forum voor debat over kwalitatief methodologische kwesties. Wie een idee heeft voor een thema of reactie wil leveren op een eerder verschenen stuk, vragen wij contact op te nemen met Jeanine Evers: j.c.evers@planet.nl.

\title{
Kwalitatief onderzoek: een keur aan werkelijkheden
}

\author{
Jeanine Evers
}

Met Harrie Jansen erger ook ik mij wel eens aan het slecht gefundeerd taalgebruik in onderzoek dat zichzelf als kwalitatief presenteert. Wat vaak Grounded Theory wordt genoemd, is het niet en wat het wel lijkt te zijn, wordt niet als zodanig benoemd (Boeije, 2005). Het is mij echter niet helemaal duidelijk aan wie Jansen zijn boodschap richt. Om te beginnen het punt dat het veldboeket aan kwalitatieve benaderingen te weinig zichtbaar zou zijn, dan wel te weinig wordt geëxpliciteerd. Vanuit die gedachte heb ik destijds voorgesteld in het tijdschrift KWALON de rubriek Stromingen op te nemen, niet alleen om het palet aan mogelijke vormen van kwalitatief onderzoek meer onder de aandacht te brengen, maar ook om de automatische connotatie van kwalitatief onderzoek met de gefundeerde theoriebenadering te nuanceren en onderzoekers te inspireren tot wat meer creativiteit in het gebruik van methoden. Als redactielid van KWALON mag dit bij Jansen bekend verondersteld worden, en het is dan ook vreemd dat hij dit niet meeneemt in zijn kritiek, zoals Paul ten Have in zijn reactie terecht opmerkt. Ook in een aantal cursussen van KWALON (kwalitatief interviewen, kwalitatieve analyse, methodologische kwaliteit, discoursanalyse) wordt expliciet ingegaan op stromingen in kwalitatief onderzoek en de implicaties daarvan voor het onderzoek, met hetzelfde doel als hiervoor voor de rubriek Stromingen is aangegeven. In de jongste publicatie van Evers (2007) waaraan zowel mensen van binnen als buiten $K W A L O N$ hebben meegewerkt, is zelfs aan auteurs gevraagd hun werk te typeren in het licht van de daar behandelde stromingen. In die zin zou je kunnen zeggen dat Jansen op zijn wenken bediend wordt.

Maar er is meer. In zijn bijdrage zet Jansen zich af tegen de term kwalitatief als parapluterm, die naar zijn beleving de term interpretatief heeft verdrongen. Dat lijkt een te vergaande versimpeling. De tegenstelling kwalitatief-kwantitatief, die naar zijn mening vooral in het kwalitatieve kamp zou worden gemunt, wordt in beide kampen gehanteerd. In het kwalitatieve kamp als kritiek op de vaak oppervlakkiger resultaten bij kwantificerend onderzoek en in het kwantitatieve kamp als kritiek op het als 'subjectief' ervaren karakter van kwalitatief onderzoek dat bovendien niet generaliseerbaar zou zijn. Inmiddels zijn er boeken vol geschreven over deze patstelling, maar zijn er ook geluiden binnen KWALON die, zoals Tineke Abma terecht opmerkt, proberen de meerwaarde te laten zien van beide benaderingen en pogen uit de patstelling weg te komen (De Boer, 2006; Boeije, 2007; Van den Berg \& Evers, 2006; Jedeloo et al., 2007). Tijdens de NOSMO-dag van maart 2007 hebben Harry van den Berg en ik laten zien hoe in ons mixed methods-onderzoek naar rassendiscri- 
minatie een kwantificerend survey en open interviews elkaar aanvulden, maar ook - tot onze grote verassing - elkaar valideerden in de uitkomsten (Evers \& Van den Berg, 2007).

Ook het idee dat de kwalitatieve werkwijze gehackt is door een humanistische maatschappijkritiek, lijkt niet helemaal terecht. Lang niet alle kwalitatief onderzoek wordt vanuit een ideologische geladenheid verricht, zelfs niet aan de Universiteit voor Humanistiek, waar een aantal van de door Jansen genoemde termen (empathisch begrijpend, empowerend en participatief) gemeengoed is. In de annexatie van kwalitatieve methodologie door een humanistische ideologie herken ik me dan ook helemaal niet. De verwijzing naar theorievorming die ophoudt bij een member check lijkt wel erg simpel en getuigt van weinig inzicht in theorievorming in kwalitatief onderzoek en de rol van de onderzoeker daarin. Tenslotte is de onderzoeker uiteindelijk verantwoordelijk voor de 'vertaling' van empirische bevindingen naar theorie, zelfs als onderzochten of andere belanghebbenden zich daar niet geheel in herkennen (Evers, 2003). De moeilijkheid zit hem er juist in om zó van die empirie weg te abstraheren dat recht wordt gedaan aan de diversiteit in de onderzoeksdata, en tegelijkertijd aan methodologische eisen wordt voldaan. Dat je daarbij een member check uitvoert, is alleen maar te waarderen, maar zeker niet beslissend. Vaak betekent het wel dat je - vanuit je ontwikkelde theorie - weer een vertaalslag moet maken naar de taal en het begrippenkader van de onderzochten. Maar dat heeft wat mij betreft meer te maken met het bereikbaar maken van je onderzoeksresultaten voor verschillende gremia dan dat het iets zegt over het abstractie- of kwaliteitsniveau van je analyse.

Tot slot de aanbevelingen die Jansen doet. De typering van kwalitatief en kwantitatief onderzoek onder back to basics lijkt mij een goed begin, maar onvoldoende uitgewerkt. Terug naar de tekentafel, zou ik zeggen. Met de gewenste taalhygiëne kan ik alleen van harte instemmen. Het laatste punt zou ik echter willen nuanceren. Het lijkt me ondoenlijk om niet te beginnen met een parapluterm als 'kwalitatief', 'kwantitatief' of 'mixed methods'. Dat dient alleen ter grove categorisatie, maar is - zeker in abstracts en dergelijke - wel nodig. Daarna zou een nuancering moeten volgen naar hoe dan precies te werk is gegaan. Ook daarin kan ik alleen maar van harte instemmen met de oproep tot specificatie.

\section{Literatuur}

Abma, T. (2007). Nieuwe wegen voor samenwerking en de integratie van methoden. KWALON 35, 12(2), p. 10-12.

Berg, H. van den \& Evers, J. (2006). Discriminatie-ervaringen 2005. Een onderzoek naar ervaringen met discriminatie op grond van land van herkomst, geloof en (huids)kleur. In: I. Boog (red.), Monitor Rassendiscriminatie 2005. Rotterdam: Landelijk Bureau ter bestrijding van Rassendiscriminatie.

Boeije, H. (2005). Analyseren in kwalitatief onderzoek. Denken en doen. Amsterdam: Boom Onderwijs.

Boeije, H. (2007). Analyze this! Van vragenlijst tot topiclist. NOSMO methodologendag, 9 maart 2007. 
Boer, F. de (2006). Mixed methods: iets nieuws? KWALON 32, 11 (2), p. 5-10.

Evers, J. (2003). Ethische professionaliteit in de rapportage. Beroepsmoraal en technische vaardigheden als complementair gegeven. In: F. Wester (red.), Rapporteren over kwalitatief onderzoek. Utrecht: Lemma.

Evers, J. \& Berg, H. van den (2007). Onderzoek naar rassendiscriminatie: de rol van kwalitatief onderzoek in een Mixed Methods Design. Nosmo Methodologendag, maart 2007.

Jedeloo, S. et al., (2007). Zorgpreferenties van jongeren met chronische aandoeningen: vier profielen. Rotterdam: Hogeschool De Gezonde Stad, Kenniskring Transities in Zorg.

\title{
Over het categoriseren van sociaalwetenschappelijk onderzoek
}

\author{
Harry van den Berg
}

\section{Inleiding}

In KWALON 35 startte Harrie Jansen vorig jaar een discussie over de manier waarop de term 'kwalitatief' gebruikt wordt en soms gecultiveerd wordt in wat hij aanduidt als 'het kwalitatieve kamp'. Zo'n kritische zelfreflectie van iemand die aan de wieg heeft gestaan van het platform en het tijdschrift met een vaandel waarin de term 'kwalitatief' een prominente plaats inneemt, is opmerkelijk. In de reacties op het artikel van Jansen worden vooral relativeringen en nuanceringen aangebracht. Paul ten Have wijst in hetzelfde KWALON-nummer op de verschillen tussen degenen die kwalitatief onderzoek verbinden met maatschappijkritische 'bevlogen' pretenties en degenen die sceptisch staan tegenover een dergelijke koppeling. Tineke Abma bepleit samenwerking en integratie van kwalitatieve en kwantitatieve methoden. Daar sluiten we ons van harte bij aan. Toch lijkt het mij goed om dieper in te gaan op de mechanismen die ten grondslag liggen aan de door Jansen gewraakte en gevreesde 'eenheidscultivering' van een bepaalde methodologische benadering van onderzoek. Mijn stelling is overigens dat 'eenheidscultivering' geen privilege is van (bepaalde stromingen binnen) kwalitatief onderzoek (zoals Jansen suggereert), maar minstens zo sterk is bij kwantitatief onderzoek. Beide processen versterken elkaar en kunnen beschouwd worden als keerzijden van eenzelfde medaille. Daarom is het relevant om die medaille nader onder de loep te nemen: het categoriseren van onderzoeksbenaderingen en met name de manier waarop die categorisering gebruikt wordt.

\section{De tweedeling 'kwalitatief' versus 'kwantitatief'}

Wie de praktijk van sociaalwetenschappelijk onderzoek in kaart probeert te brengen, stuit op een onoverzichtelijke variatie van onderzoeksbenaderingen, methoden en analysetechnieken. Daarom is het niet verrassend dat vanaf het ontstaan van die sociale wetenschap- 